Vol. 13 (2004): 29-38.

\title{
Impact dehulling oat grain to improve quality of on-farm produced feed 2. Groat breakage and storability
}

\author{
Pirjo Peltonen-Sainio \\ MTT Agrifood Research Finland, Plant Production Research, FIN-31600 Jokioinen, Finland, \\ e-mail: pirjo.peltonen-sainio@mtt.fi \\ Pekka Lehtinen \\ Helsinki University of Technology, Laboratory of Biochemistry and Microbiology, PO Box 6100, \\ FIN-02015 TKK, Finland \\ Markku Kontturi, Ari Rajala \\ MTT Agrifood Research Finland, Plant Production Research, FIN-31600 Jokioinen, Finland \\ Anna-Maija Kirkkari \\ Work Efficiency Institute, PO Box 13, FIN-05201 Rajamäki, Finland
}

\begin{abstract}
Dehulling improves markedly the feed value of oat (Avena sativa L.), but good storability of groat mass is required when large quantities of oat are dehulled at any one time. A laboratory model of an impact oat dehuller, similar to a commercial device, was used to study the effects of rotation speed and grain moisture content on groat breakage and the storage life of oat groats. Grain of oat cultivar Salo [from official variety trials, MTT Agrifood Research Finland, Jokioinen $\left(60^{\circ} 49^{\prime} \mathrm{N}\right), 1_{1996-2000}$ ] was dehulled with an impact oat dehuller using rotation speeds of 200 to $500 \mathrm{r} \mathrm{min}^{-1}$ at $50 \mathrm{rmin}{ }^{-1}$ intervals. In an additional experiment, grains were moistened resulting in moisture content ranging from $10 \%$ to $18 \%$. Proportion of broken groats and size distribution of groat particles were measured. Storability was determined through analysing the evolution of pentanal, hexanal and free fatty acid content after storing groats at 10,20 and $30^{\circ} \mathrm{C}$ for two and five months. At higher rotation speeds more broken groats resulted, but dehulling did not cause any marked rancidification of the groats. Thus, impact dehulling is a practical method to increase the energy content of oat grains on-farm without such problems as groat breakage induced oxidation of fatty acids.
\end{abstract}

Key words: Avena sativa, fat, fatty acids, grain, groat, hulls, oat, rancidification, rotational speed, volatile compounds 


\section{Peltonen-Sainio, P. et al. Impact dehulling oat grain: groat breakage and storability}

\section{Introduction}

Oat (Avena sativa L.) grain is excellent in nutritional quality and has high metabolised energy content compared with other small-grain cereals, but only when hulls surrounding the caryopsis are removed (Peltonen-Sainio et al. 2004). High hull content of oat is a major reason for predomination of barley (Hordeum vulgare L.) and wheat (Triticum aestivum L.) as feed crop in many countries (Burrows 1986). Despite considerable plant breeding efforts and significant progress in reducing hull content in conventional oat (Rekunen 1988, Souza and Sorrells 1988, Forsberg and Reeves 1992), the overall presence of hulls limits the attractiveness of oat as feed.

Naked oat that lacks hulls or have thin and papery ones when not completely naked, offers a promising alternative for nutrient dense, low fibre diets. Encouraging results have been obtained in feeding experiments with horses, pigs, poultry and cattle (Cave and Burrows 1985, Maurice et al. 1985, Myer et al. 1985, Givens and Brunnen 1987, Cave et al. 1990, Hsun and Maurice 1992, MacLean et al. 1994, Poste et al. 1996). In spite of these systematic positive results, naked oat has not yet replaced conventional oat to a significant degree. However, partially dehulled oat groats have resulted in similar results to those for naked oat in feeding experiments (Pettersson et al. 1987, 1997). Hence, onfarm dehulling of conventional oat is considered to be a valid alternative to growing naked oat (Peltonen-Sainio et al. 2004).

When targeting improved nutritive value and energy content for oat based diet, the farmer can either invest in an oat dehuller or have dehulling done as an external service. Mechanical dehulling causes groat damage (Symons and Fulcher 1988, Doehlert et al. 1999). Groat breakage may cause economic losses by increasing proportion of wastage (Peltonen-Sainio et al. 2004), but it can also activate endogenous lipase and lipoperoxidase in oat groat. Oat lipase is mainly localised in the aleurone layer and embryonic tissues (Ekstrand et al. 1992), both of which are likely to be damaged during rough dehulling. Following these enzymatic reactions, a decrease in the quality of groat results from formation of free fatty acids (FFA) and the oxidation products of unsaturated fatty acid moieties of oat lipid (Bodin 1995, Molteberg et al. 1995). As farmers prefer to have large quantities of dehulled oat at any one time, it is important to know how dehulling affects storability of groat mass. The storage time may also depend on, for example, adjustments of the dehuller and quality of the oat grains being dehulled. Hence, the experiments reported here were carried out to evaluate the effects of dehulling on groat breakage and storability of groats through assessing oxidation of fatty acids; content of FFA and release of volatile compounds including pentanal and hexanal.

\section{Material and methods}

Grain of oat cultivar Salo was obtained from official variety trials carried out at MTT Agrifood Research Finland, Jokioinen $\left(60^{\circ} 49^{\prime} \mathrm{N}\right)$ in $1996-$ 2000. Background information for the experiments are shown in Kangas et al. (2001) and Peltonen-Sainio et al. (2004). Grain from each year was pre-purified by sorting with $1.5 \mathrm{~mm}$ sieves to remove immature grains, small particles, dust and weed seeds prior to all measurements and analyses.

\section{Rotation speed effects of impact oat dehuller (Experiment I)}

Ten kilograms of pre-purified grains of oat cultivar Salo from 2000 were used as raw material for the experiment. Three $250 \mathrm{~g}$ sub-samples were dehulled at rotation speeds of 200, 250, $300,350,400,450$ and $500 \mathrm{r} \mathrm{min}^{-1}$ with an impact oat dehuller (Rivakka, Nipere Ltd., Finland, http://www.nipere.fi) as demonstrated by Peltonen-Sainio et al. (2004). After dehulling, a $50 \mathrm{~g}$ sub-sample representing groat yield was ana- 
Vol. 13 (2004): 29-38.

lysed for unbroken groats ( $\mathrm{g}$ ) and broken groats and groat particles $(\mathrm{g})$ and their relative proportions were calculated. The remaining groat yields (that included also hulls at degree dependent on rotation speed) from each of dehulled sub-samples subjected to different rotation speeds were used for analysing storability of dehulled groats at Helsinki University of Technology (see below). Additional grain samples of cultivar Salo from 2001 with single grain weight averaging $39.7 \mathrm{mg}$ were dehulled using different rotation speeds. Number and weight (g) of unbroken groats and broken groats, together with groat particles, were measured above each sieve (width $2.6 \mathrm{~mm}, 2.4 \mathrm{~mm}, 2.2 \mathrm{~mm}, 2.0 \mathrm{~mm}, 1.8 \mathrm{~mm}, 1.5$ $\mathrm{mm}$ and $1.2 \mathrm{~mm}$, length always $20 \mathrm{~mm}$ ) used for sorting. Also average single groat weight (unbroken, completely naked, $\mathrm{mg}$ ) for each size class and rotation speed was determined.

\section{Effects of year and grain moisture on groat breakage (Experiment 2)}

Pre-purified grain of oat cultivar Salo harvested in 1996-2000 were used as the raw material for the experiment. Three sub-samples, each weighing $500 \mathrm{~g}$, were dehulled with a Nipere dehuller using a rotation speed of $350 \mathrm{r} \mathrm{min}^{-1}$, which was fixed on the basis of Peltonen-Sainio et al. (2004). After dehulling the replicate oat samples from different years, a $50 \mathrm{~g}$ sub-sample representing groat yield was analysed for unbroken groats $(\mathrm{g})$ and broken groats and groat particles (g) and their relative proportions on completely dehulled groat mass were calculated.

A moisturising treatment experiment was carried out as shown by Peltonen-Sainio et al. (2004). Nine moisture content classes were determined: $10.3-10.5 \%$ (depending on treated sub-sample), $11.4-11.5 \%, 12.4-12.5 \%, 13.2-$ $13.5 \%, 14.1-14.4 \%, 15.4-15.5 \%, 16.3-16.4 \%$, $17.3-17.4 \%$ and $18.5-18.7 \%$. Three replicate samples per moisture content class, each weighing $150 \mathrm{~g}$, were dehulled at a rotation speed of $350 \mathrm{r} \mathrm{min}^{-1}$. Proportions of unbroken groats and broken groats and groat particles were analysed from fully dehulled groat mass as in Experiment 1 .

\section{Storability of dehulled oat groats (Experiment 3)}

Groat yield from Experiment 1 was stored in sealed boxes at 10,20 and $30^{\circ} \mathrm{C}$ for five months. The initial amount of air in the headspace of sample was $23.2 \mathrm{ml} \mathrm{g}^{-1}$ groat. The highest temperature was regarded as an extreme reference that is likely to enhance rancidification of oat groats, while dehulled groat mass is likely to face 10 and $20^{\circ} \mathrm{C}$ storage temperatures on-farm. After storage the amount of FFA and volatile lipid oxidation products were analysed. Volatile lipid oxidation products were also analysed after two months of storage. Free fatty acids were determined as described by Liukkonen et al. (1992). For the FFA determination, the lipids were extracted using a modified Folch method. Free fatty acids were separated from the extract by thinlayer chromatography and FFA were quantified by converting fatty acids into methyl ester and analysis by gas chromatography. Volatile lipid oxidation products were determined as described in Heiniö et al. (2002). Briefly, headspace composition of the sample was determined by static headspace measurement. Prior to the measurement the sealed vials were equilibrated at $100^{\circ} \mathrm{C}$ for 25 minutes. The headspace sample was then fed into a gas chromatograph equipped with a mass selective detector. The detector signals were calibrated using an external standard and all data were normalized so that for each compound, the maximum response during the whole 5-month storage period was set to unity.

\section{Statistical analysis}

Significant differences among years, grain moisture contents and effects of different rotation speeds of the dehuller were established using PROC MIXED software (Littell et al. 1996). Data were considered to be completely ran- 


\section{Peltonen-Sainio, P. et al. Impact dehulling oat grain: groat breakage and storability}

domised (three replicates). In the model, different grain moisture contents, rotation speeds and years were considered as fixed effects. Correlations between rotation speed of the dehuller and evolved/measured volatile compounds shortly after dehulling, and after 57 and 153 d storage, were estimated using PROC CORR of SAS.

\section{Factors affecting groat breakage \\ Unhulled grains and broken groats were present in dehulled groat mass in addition to unbroken groats. Proportions of these fractions in groat mass changed according to rotation speed of the impact dehuller (Fig. 1). There was a clear trend that up to a rotation speed of $350 \mathrm{r} \mathrm{min}^{-1}$ less than $4 \%$ of dehulled groats were broken. Above this speed the proportion of broken groats dou- bled with each increase in rotation speed of $50 \mathrm{r}$ $\mathrm{min}^{-1}$ and was about $28 \%$ at $500 \mathrm{r} \mathrm{min}^{-1}$. Propor- tion of unbroken groats and concomitantly bro- ken groats differed by some 10 percentage units at most depending on year (Table 1). Increase in grain moisture content resulted in fewer broken}

Table 1. Proportion of unbroken and broken groats in completely dehulled groats of oat grown in 1996-2000 when impact dehulled by using a fixed rotation speed of $350 \mathrm{r}$ $\min ^{-1}$.

\begin{tabular}{lcc}
\hline Year & \multicolumn{2}{c}{ Proportion of groats $(\%)$} \\
\cline { 2 - 3 } & Unbroken & Broken \\
\hline 1996 & $98.9 \mathrm{a}$ & $1.1 \mathrm{c}$ \\
1997 & $96.5 \mathrm{~b}$ & $3.5 \mathrm{~b}$ \\
1998 & $96.6 \mathrm{~b}$ & $3.4 \mathrm{~b}$ \\
1999 & $89.4 \mathrm{c}$ & $10.6 \mathrm{a}$ \\
2000 & $96.3 \mathrm{~b}$ & $3.7 \mathrm{~b}$ \\
Mean & 95.5 & 4.5 \\
\hline
\end{tabular}

Means within each column not followed by the same letter are significantly different at $\mathrm{P} \leq 0.05$.
Table 2. Effects of grain moisture content prior to impact oat dehulling on proportion of unbroken and broken groats in completely dehulled groats, when impact dehulled using a fixed rotation speed of $350 \mathrm{r} \mathrm{min}^{-1}$.

\begin{tabular}{lcc}
\hline $\begin{array}{l}\text { Grain moisture } \\
\text { content }(\%)\end{array}$ & \multicolumn{2}{c}{ Proportion of groats $(\%)$} \\
\cline { 2 - 3 } & Unbroken & Broken \\
\hline 10.4 & $87.6 \mathrm{e}$ & $12.4 \mathrm{a}$ \\
11.5 & $91.0 \mathrm{~d}$ & $9.0 \mathrm{~b}$ \\
12.4 & $92.3 \mathrm{~d}$ & $7.7 \mathrm{~b}$ \\
13.3 & $96.6 \mathrm{abc}$ & $3.4 \mathrm{cde}$ \\
14.2 & $95.0 \mathrm{bc}$ & $5.0 \mathrm{~cd}$ \\
15.4 & $97.2 \mathrm{abc}$ & $2.8 \mathrm{cde}$ \\
16.4 & $98.1 \mathrm{ab}$ & $1.9 \mathrm{de}$ \\
17.4 & $98.6 \mathrm{ab}$ & $1.4 \mathrm{de}$ \\
18.6 & $98.5 \mathrm{ab}$ & $1.5 \mathrm{de}$ \\
\hline
\end{tabular}

Means within each column not followed by the same letter are significantly different at $\mathrm{P} \leq 0.05$.

groats in the dehulled groat mass (Table 2). This reduction was at most 11 percentage units.

Detailed analysis of groat particle size after dehulling indicated that as rotation speed increased the number of broken groats and groat particles in different size groups steadily increased (Fig. 2). Small groat particles were particularly numerous at high rotation speeds, while up to $300 \mathrm{r} \mathrm{min}^{-1}$ the number of broken groats and groat particles was the same in all size groups. Sorting unbroken groats into seven groups according to size showed that above a rotation speed of 300-350 $\mathrm{r} \mathrm{min}^{-1}$ the number of naked groats characterized as low weight increased while high weight groats decreased. Mean single groat weight of unbroken groats decreased steadily as rotation speed increased.

\section{Storability of impact dehulled oat mass}

Despite the relatively large proportion of broken groats in dehulled oat samples, lipase catalysed hydrolysis of acylglycerols was minimal during subsequent storage of dehulled groats. At the end of a five-month storage period, in intact control grains the proportion of FFA was 5.5\%, while at 200,300, 400 and $500 \mathrm{r} \mathrm{min}^{-1}$ the pro- 
Vol. 13 (2004): 29-38.

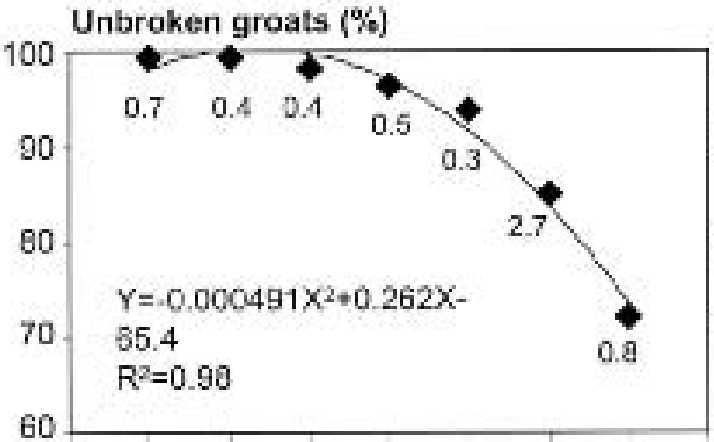

150

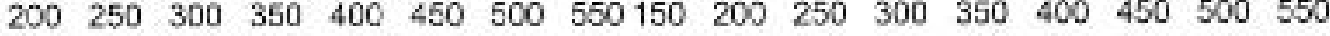 \\ Rotation speed of oat dehuller ( $\left.\mathrm{r} \mathrm{min}^{-1}\right)$}

Fig. 1. Effects of rotation speed of the impact oat dehuller on proportion of unbroken and broken groats and unhulled grains in groat yield. Standard deviations are shown as values next to each legend.
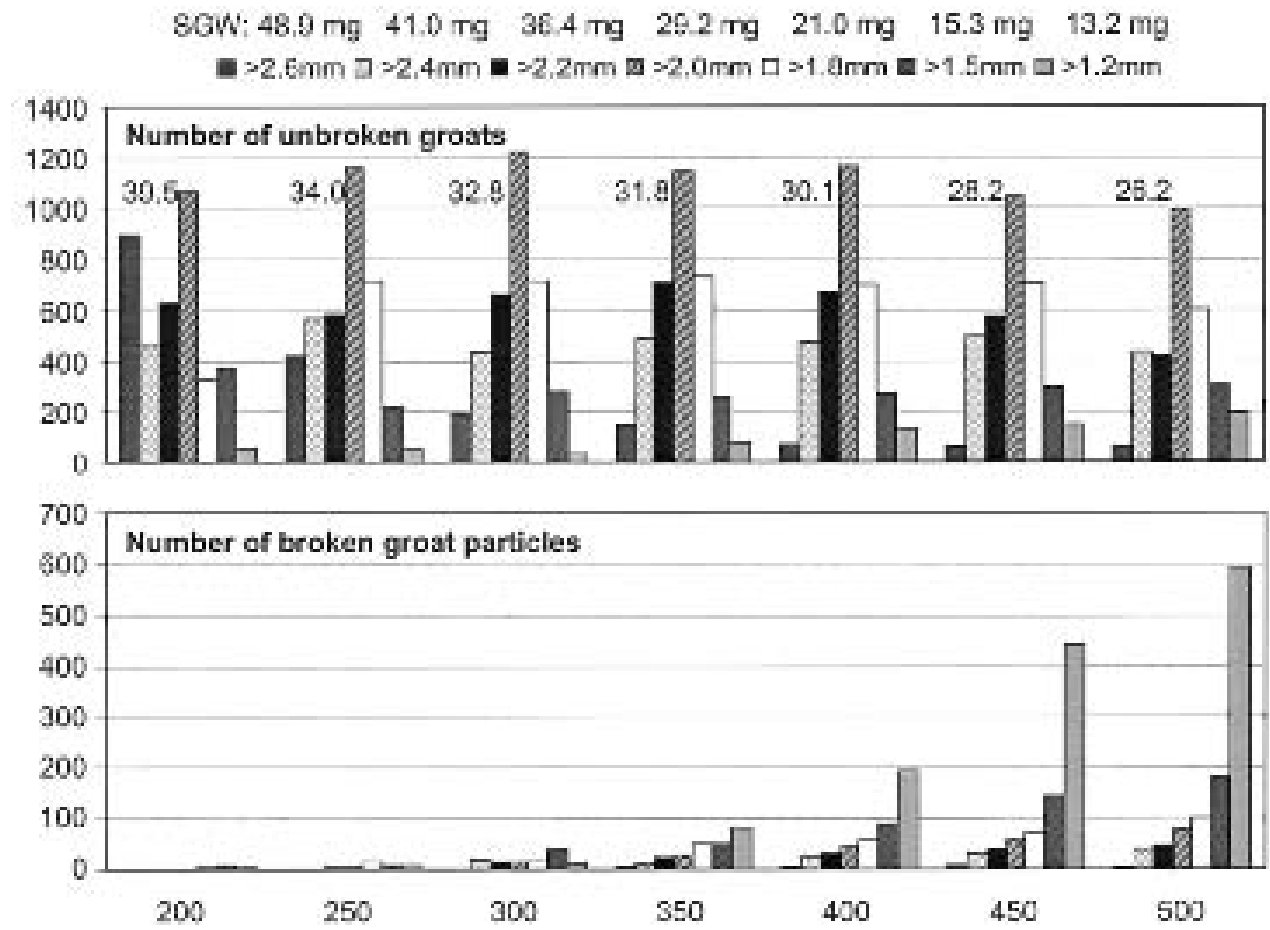

Roiation speed of oal dehuller ( $\left(\mathrm{min}^{-1}\right)$

Fig. 2. Effects of rotation speed of the impact oat dehuller on size distribution of unbroken (consists of both naked groats and hull retaining grains) and broken groats in groat yield. Mean single groat weight (SGW) of completely dehulled groats for each size group is shown above the figure and for each rotation speed next to the bars. The single grain weight of intact grains prior to dehulling was $39.7 \mathrm{mg}$. 


\section{Peltonen-Sainio, P. et al. Impact dehulling oat grain: groat breakage and storability}

portions were $5.3 \%, 5.7 \%, 6.6 \%$ and $7.9 \%$, respectively. Hence, there was a tendency for higher rotation speed to result in a slightly higher content of FFA. At most the proportion of FFA was ca. 2.5 percentage units higher than was noted in the control sample that was not dehulled.

No sign of oxidation of unsaturated fatty acid moieties in dehulled groats was evident during storage. Concentrations of volatile oxidation products, pentanal and hexanal, in the sample headspace were actually lower in the dehulled oat groat than in the control grains. Concentrations of numerous measured volatile compounds, also others than those associating oxidation of fatty acids, reduced as rotation speed increased (Table 3). This was independent of storage time (Table 3). In all samples the amount of pentanal and hexanal decreased during storage, indicating that no marked oxidation of unsaturated fatty acids occurred during the storage period (Fig. 3).

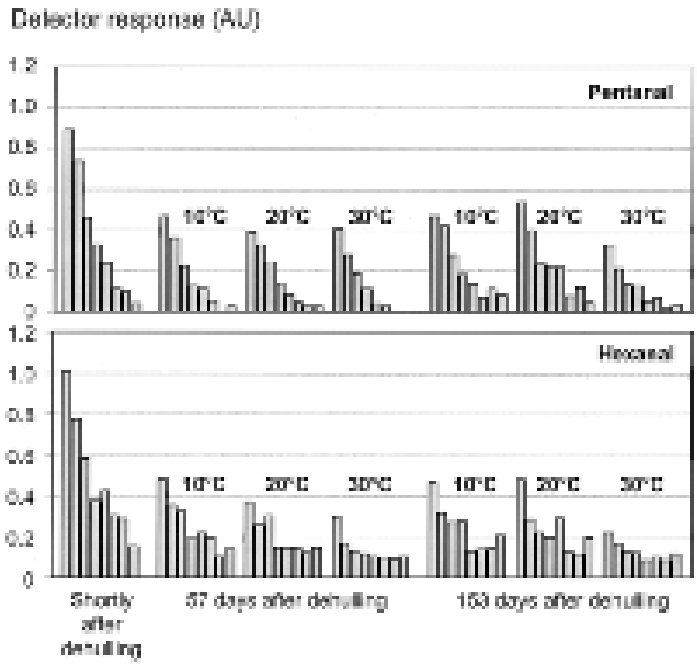

Fig. 3. Content of volatile compounds, pentanal and hexanal, on oat groat yield dehulled using different rotation speeds when measured shortly after dehulling and after storing groats from 57 and 153 days at 10,20 and $30^{\circ} \mathrm{C}$. In each cluster of bars the leftmost bar is unhulled control and when moving rightward, the rotation speed of oat dehuller increases from 200 to $500 \mathrm{r} \mathrm{min}^{-1}$ at $50 \mathrm{r} \mathrm{min}^{-1}$ intervals.

Table 3. Significant Pearson correlation coefficients for association between rotation speed of oat dehuller and volatile compounds measured shortly after dehulling and after storing for 57 and 153 days at $10^{\circ} \mathrm{C}, 20^{\circ} \mathrm{C}$ and $30^{\circ} \mathrm{C}(\mathrm{n}=8)$.

\begin{tabular}{|c|c|c|c|c|c|c|c|}
\hline \multirow{2}{*}{$\begin{array}{l}\text { Volatile } \\
\text { compound }\end{array}$} & \multirow{2}{*}{$\begin{array}{c}\text { Shortly } \\
\text { after } \\
\text { dehulling }\end{array}$} & \multicolumn{3}{|c|}{ After storing for 57 days at } & \multicolumn{3}{|c|}{ After storing for 153 days at } \\
\hline & & $10^{\circ} \mathrm{C}$ & $20^{\circ} \mathrm{C}$ & $30^{\circ} \mathrm{C}$ & $10^{\circ} \mathrm{C}$ & $20^{\circ} \mathrm{C}$ & $30^{\circ} \mathrm{C}$ \\
\hline Dimethylsulfide & $-0.86 * *$ & & & & & & $0.88 * *$ \\
\hline Isobutyraldehyde & $-0.96 * * *$ & $-0.90 * *$ & $-0.92 * *$ & $-0.96 * * *$ & $-0.80 *$ & $-0.87 * *$ & $-0.97 * * *$ \\
\hline 3-methyl butanal & $-0.98 * * *$ & $-0.93 * * *$ & $-0.93 * * *$ & $-0.95 * * *$ & $-0.86^{* *}$ & $-0.95 * * *$ & $-0.95 * * *$ \\
\hline 2-methyl butanal & $-0.97 * * *$ & $-0.89 * *$ & $-0.93 * * *$ & $-0.94 * * *$ & $-0.79 *$ & $-0.90 * *$ & $-0.97 * * *$ \\
\hline Pentanal & $-0.97 * * *$ & $-0.97 * * *$ & $-0.95 * * *$ & $-0.97 * * *$ & $-0.93 * * *$ & $-0.97 * * *$ & $-0.97 * * *$ \\
\hline 1-pentanol & $-0.90 * *$ & & & $-0.87 * *$ & & $-0.74 *$ & $-0.97 * * *$ \\
\hline Hexanal & $-0.97 * * *$ & $-0.96 * * *$ & $-0.89 * *$ & $-0.92 * *$ & $-0.90 * *$ & $-0.87 * *$ & $-0.87 * *$ \\
\hline Trans-2-hexanal & $-0.95 * * *$ & $-0.98 * * *$ & $-0.93 * * *$ & $-0.91 * *$ & $-0.89 * *$ & $-0.97 * * *$ & $-0.85 * *$ \\
\hline 1-hexanol & $-0.99 * * *$ & $-0.94 * * *$ & $-0.92 * *$ & $-0.95 * * *$ & & $-0.71 *$ & $-0.79 *$ \\
\hline Heptanal & $-0.97 * * *$ & $-0.96 * * *$ & $-0.95 * * *$ & $-0.92 * *$ & $-0.92 * *$ & $-0.96 * * *$ & $-0.89 * *$ \\
\hline Pentyl furan & $-0.98 * * *$ & $-0.98 * * *$ & $-0.81 *$ & $-0.90 * *$ & $-0.86 * *$ & $-0.79 *$ & \\
\hline Phenylacetate & $-0.82 *$ & & $-0.84 * *$ & $-0.92 * *$ & & & $-0.71 *$ \\
\hline Nonanal & $-0.98 * * *$ & $-0.97 * * *$ & $-0.98 * * *$ & $-0.75^{*}$ & $-0.76 *$ & $-0.75^{*}$ & \\
\hline
\end{tabular}

$* * * \mathrm{P} \leq 0.001, * * 0.001<\mathrm{P} \leq 0.01, * 0.01<\mathrm{P} \leq 0.05$ 
Vol. 13 (2004): 29-38.

\section{Discussion}

Impact dehulling of oat grains consistently and markedly improved their nutritive value and energy content (Peltonen-Sainio et al. 2004). Furthermore, results from this study indicate that dehulling does not result in the rapid deterioration of quality caused by rancidity of groat mass, despite oat groat being rich in fat and very prone to going rancid when crushed or milled. These findings further encourage the use of oat impact dehulling as a prominent alternative when nutrient dense, low fibre diets are desired on-farm.

\section{Factors affecting groat breakage of oat}

Hullability, the ease of removal of caryopsisencapsulating hulls, was better the higher the rotation speed (Peltonen-Sainio et al. 2004), but more broken groats resulted. $350 \mathrm{r} \mathrm{min}^{-1}$ was determined to be the best rotation speed. It is a compromise between an increase in energy content of oat groat mass (Peltonen-Sainio et al. 2004) and increasing groat breakage (Fig. 1). Groat particle size analysis done after dehulling with varying rotation speeds indicated that as rotation speed increased the number of broken groats and groat particles in different size groups steadily increased (Fig. 2). Small groat particles were particularly abundant at high rotation speeds. Beyond a rotation speed of 300-350 r $\min ^{-1}$ fewer unbroken high weight groats compared with low weight groats were evident in the groat mass. This indicates that the large groats were particularly sensitive to breakage during dehulling, as also shown by Symons and Fulcher (1988). A rotation speed of $350 \mathrm{r} \mathrm{min}^{-1}$ was a turning point in breakage of groats. Up to $350 \mathrm{r}$ $\min ^{-1} \leq 4 \%$ of groats were broken, while the proportion of broken groats doubled with each $50 \mathrm{r}$ $\mathrm{min}^{-1}$ increase in rotation speed above this, ending at about $28 \%$ at $500 \mathrm{r} \mathrm{min}^{-1}$ (Fig. 1). Sensitivity to groat breakage may, however, depend not only on physical characteristics of groat but also on hull characteristics. Doehlert et al. (1999) indicated that thicker hulls better protect groats against breakage. Furthermore, growing conditions also caused variability in groat breakage in studies of Doehlert and McMullen (2000). According to our data the proportion of broken groats differed at most by 9 percentage units when a fixed rotation speed of $350 \mathrm{r} \mathrm{min}^{-1}$ was used (Table 1). Exceptionally high number of broken groats were found in dehulled groat yield from year 1999. In that case hectolitre weight was low and hull content very high - evidently resulting from a very short grain-filling period compared to the other years studied (PeltonenSainio et al. 2004).

Detailed analysis of groat particle size after dehulling gave additional information on hullability, by indicating that higher rotation speed resulted in higher numbers of low weight, unbroken groats (Fig. 2). This suggests that the small grains tend to need higher rotation speeds to be released from their hulls. However, this result may be slightly biased due to the possible abrasion of groats caused by high rotation speeds though no visual signs were evident.

Grain moisture content prior to dehulling affected breakage of groats, which was highest at low grain moisture (Table 2), as reported by Doehlert and McMullen (2001). Grain moisture content can alter groat hardness, which may be an important, though not fully studied, determinant of breakage sensitivity in oat (Doehlert and McMullen 2000). Thus, in order to get high groat yield together with a high energy content, i.e. a relatively low number of retained hulls, a grain moisture content close to the upper limit for storable cereal grain (12-14\%) is a reasonable compromise. This also results in modest groat breakage, although this was not found to be critical in terms of reducing the storage life of groat mass.

\section{Storability of dehulled groat mass}

Lipase-catalysed lipid hydrolysis is an established property of oat products. This reaction is initiated by milling and leads to a loss of quality in processed oat unless the lipase is denatured, 


\section{Peltonen-Sainio, P. et al. Impact dehulling oat grain: groat breakage and storability}

for example by steaming. In the present study, the high rotation speed during dehulling was linked with increased grain breakage. In turn this breakage was linked to the degree of lipid hydrolysis occurring during subsequent storage. However, despite groat breakage, lipid hydrolysis was at acceptable level, and after five months storage the proportion of FFA among total fatty acids was $8 \%$ at most (at the highest rotation speed). If the groat had been milled prior to storage, the expected value would be markedly higher; $20-30 \%$ of total fatty acids or more (Heiniö et al. 2002, Lehtinen et al. 2003). This rather surprising observation does not identify groat breakage as a critical factor in determining the storage stability of groat, at least in terms of lipid hydrolysis. It is, however, notable that groat moisture content was low during storage and hence, the groat was not exposed to moisture enhanced increase in FFA and/or volatile compounds (Welch 1977).

During storage no formation of volatile oxidation products of unsaturated fatty acid moieties in oat lipids was detected (Fig. 3). Two compounds studied, pentanal and hexanal, are decomposition products of hydroperoxide linoleic acid, and are formed in abundance during oxidation of linoleic acid in oat products (Heydanek and McGorrin 1981, Lehtinen et al. 2003). However, in the groat samples studied these compounds did not increase in abundance during storage, but slightly decreased regardless of storage temperature. These data do not however rule out the possibility that other lipid oxidation products were formed. For example, enzyme active oat has a high lipoperoxidase activity, which converts the hydroperoxide linoleic acid into hydroxy fatty acids. Even though these hydroxy fatty acids are non-volatile and probably have little influence on rancidity, it has been suggested that they are partially responsible for the bitter taste often linked with stored oat products (Biermann and Grosch 1979).

The tendency of dehulled groat to contain fewer volatile compounds than non-processed control material after storing for two and five months was noted. Furthermore, at the high ro- tation speeds fewer volatiles were recorded than at the lower rotation speeds (Fig. 3). This could indicate that dehulling reduced the initial amount of the volatile compounds by ventilating the grain. This is supported by the findings that all the analysed volatile compounds correlated negatively with rotation speed of the impact oat dehuller (Table 3). During subsequent storage, the formation of these compounds is apparently very slight and thus groat dehulled at high rotation speed maintained the lower level of volatiles throughout the storage period. This was also the case at extreme storage temperature of $30^{\circ} \mathrm{C}$, which is not likely to occur with on-farm storage of dehulled groat mass in northern growing conditions.

In conclusion, our results indicate that even though oat groat breakage increased with the higher mechanical stress involved by impact dehulling, this did not cause storage problems associated with lipid deterioration.

Acknowledgements. The technical assistance of Arto Timonen and Aino Lahti at MTT Agrifood Research Finland is gratefully acknowledged.

\section{References}

Biermann, U. \& Grosch, W. 1979. Bitter-tasting monoglycerides from stored oat flour. Zeitschrift für Lebensmittel- Untersuchung und -forschung 169: 22-26.

Bodin, B. 1995. Oats in human nutrition - impact of cropping environment on oat groat nutrient content and tendency to rancidify. Crop Production Science 24. $46 \mathrm{p}$.

Burrows, V.D. 1986. Breeding oats for food and feed: conventional and new techniques and materials. In: Webster, F.H. (ed.). Oats: chemistry and technology. American Association of Cereal Chemists, St. Paul, Minnesota, USA. p. 13-46.

Cave, N.A. \& Burrows, V.D. 1985. Naked oats in feeding the broiler chicken. Poultry Science 64: 771-773.

Cave, N.A., Wood, P.J. \& Burrows, V.D. 1990. The nutritive value of naked oats for broiler chicks as affected by dietary addition of oat gum, enzyme, antibiotic, bile salt and fat soluble vitamins. Canadian Journal of Animal Science 70: 623-633.

Doehlert, D.C. \& McMullen, M.S. 2000. Genotypic and environmental effects of oat milling characteristics and groat hardness. Cereal Chemistry 77: 148-154. 
Vol. 13 (2004): 29-38.

Doehlert, D.C. \& McMullen, M.S. 2001. Optimizing conditions for experimental oat dehulling. Cereal Chemistry 78: 675-679.

Doehlert, D.C., McMullen, M.S. \& Baumann, R.R. 1999. Factors affecting groat percentage in oat. Crop Science 39: 1858-1865.

Ekstrand, B., Gangby, I. \& Åkesson, G. 1992. Lipase activity in oats - distribution, $\mathrm{pH}$ dependence, and heat inactivation. Cereal Chemistry 69: 379-381.

Forsberg, R.A. \& Reeves, D.L. 1992. Breeding oat cultivars for improved grain quality. In: Marshall, H.G. \& Sorrells, M.E. (eds.). Oat Science and Technology. Agronomy 33. American Society of Agronomy Inc. and Crop Science Society of America Inc. Publishers, Madison, Wisconsin. P. 751-775.

Givens, D.I. \& Brunnen, J.M. 1987. Nutritive value of naked oats for ruminants. Animal Feed Science and Technology 18: 83-87.

Heiniö, R.L., Lehtinen, P., Oksman-Caldentey, K.M. \& Poutanen, K. 2002. Differences between sensory profiles and development of rancidity during long-term storage of native and processed oat. Cereal Chemistry 79: 367-375.

Heydanek, M. \& McGorrin, R. 1981.Gas chromatography-mass spectroscopy identification of volatiles from rancid oat groats. Journal of Agricultural and Food Chemistry 29: 1093-1095.

Hsun, C.-L. \& Maurice, D.V. 1992. Nutritional value of naked oats (Avena nuda) in laying hen diets. An International Journal 33: 355-361.

Kangas, A., Laine, A., Niskanen, M., Salo, Y., Vuorinen, M., Jauhiainen, L. \& Mäkelä, L. 2001. Results of official variety trials 1993-2000. MTT publications, Series $A$ 94. Jokioinen, Finland. 262 p.

Lehtinen, P., Kiiliäinen, K., Lehtomäki, I. \& Laakso, S. 2003. Effect of heat treatment on lipid stability in processed oats. Journal of Cereal Science 37: 215221.

Littell, R.C., Milliken, G.A., Stroup, W.W. \& Wolfinger, R.D. 1996. SAS system for mixed models. Cary, NC: SAS Institute Inc. 633 p.

Liukkonen, K.H., Montfoort, A. \& Laakso, S. 1992. Water-induced lipid changes in oat processing. Journal of Agricultural and Food Chemistry 40: 126-130.

MacLean, J., Webster, A.B. \& Anderson, D.M. 1994. Naked oats in grower and finisher diets for male chick- en roasters and female turkey broilers. Canadian Journal of Animal Science 74: 135-140.

Maurice, D.V., Jones, J.E., Hall, M.A., Castaldo, D.J. \& Whesenhunt, J.E. 1985. Chemical composition and nutritive value of naked oats (Avena nuda L.) in broiler diets. Poultry Science 64: 529-535.

Molteberg, E.L., Vogt, G., Nilsson, A. \& Frolich, W. 1995. Effects of storage and heat processing on the content and composition of free fatty acids in oats. $\mathrm{Ce}$ real Chemistry 72: 88-93.

Myer, R.O., Barnett, R.D. \& Walker, W.R. 1985. Evaluation of hull-less oats (Avena nuda L.) in diets for young swine. Nutrition Reports International 32: 1273-1277.

Peltonen-Sainio, P., Kontturi, M., Rajala, A. \& Kirkkari, A.-M. 2004. Impact dehulling oat grain to improve quality of on-farm produced feed 1 . Hullability and associated changes in nutritive value and energy content. Agricultural and Food Science 13: 18-28.

Pettersson, D., Graham, H. \& Åman, P. 1987. The productive value of whole and dehulled oats in broiler chicken diets, and influence of b-glucanase supplementation. Nutrition Reports International 36: 743750.

Pettersson, Å., Lindberg, J.E. \& Thomke, S. 1997. Nutritive value of oats of different composition evaluated by intact and fistulated pigs. Acta Agriculturæ Scandinavica, Section A, Animal Science 47: 247-253.

Poste, L.M., Butler, G., Cave, N.A. \& Burrows, V.D. 1996. Sensory analysis of meat from broiler chickens fed diets containing hulless oats (Avena nuda). Canadian Journal of Animal Science 76: 313-319.

Rekunen, M. 1988. Advances in breeding of oats. Comparative trials with historical varieties in 1977-87. Journal of Agricultural Science in Finland 60: 307321.

Souza, E.J. \& Sorrells, M.E. 1988. Mechanical mass selection methods for improvement of oat groat percentage. Crop Science 28: 618-623.

Symons, S.J. \& Fulcher, R.G. 1988. Relationship between oat kernel weight and milling yield. Journal of Cereal Science 7: 215-217.

Welch, R.W. 1977. The development of rancidity in husked and naked oats after storage under various conditions. Journal of the Science of Food and Agriculture 28: 269-274. 
Peltonen-Sainio, P. et al. Impact dehulling oat grain: groat breakage and storability

\title{
SELOSTUS
}

\section{Kauran kuorinnan aiheuttama jyvien rikkoutuminen ei heikennä säilyvyyttä}

\author{
Pirjo Peltonen-Sainio, Pekka Lehtinen, Markku Kontturi, Ari Rajala ja Anna-Maija Kirkkari \\ MTT (Maa- ja elintarviketalouden tutkimuskeskus), Teknillinen korkeakoulu ja Työtehoseura ry
}

Kotoisen kaurarehun laatua voidaan parantaa huomattavasti kuorinnalla. Kuorittaessa kauran jyvä saattaa kuitenkin vaurioitua, jolloin rasvoja hajottavat entsyymit aktivoituvat. Tämä saattaa johtaa rasvojen härskiintymiseen, mikä heikentää säilyvyyttä. Tutkimuksessa selvitettiin, kuinka Rivakka-keskipakokuorijan (Nipere Oy) säädöt ja kuorittavan kauraraakaaineen laatu vaikuttavat jyvien rikkoutumiseen ja säilyvyyteen varastoitaessa kuorittua ydinmassaa eri lämpötiloissa.

Kauran kuorintakokeet järjestettiin Maa- ja elintarviketalouden tutkimuskeskuksessa (MTT). Jokioisilla, virallisissa lajikekokeissa vuonna 2000 kasvatettua Salo-kauran jyväsatoa kuorittiin useilla eri kierrosnopeuksilla (200-500 kierrosta minuutissa). Tutkimustulokset osoittivat, että rikkoutuneiden ytimien osuus kasvoi kierrosnopeuden lisääntyessä. Hyväksi kierrosnopeudeksi osoittautui 350 kierrosta minuutissa, koska tällöin rikkoutuminen oli kohtuullista (alle $5 \%$ ). Toisaalta jyvien rikkoutuminen ei lisännyt rasvojen hapettumista korkeissakaan varastointilämpötiloissa, kun sitä mitattiin haihtuvien yhdisteiden (pentanaali ja heksanaali) tuotantona. Vaikka korkeat kierrosnopeudet lisäsivät vapaiden rasvahappojen osuutta, jäivät pitoisuudet enimmilläänkin niin pieniksi, etteivät ne aiheuttane esimerkiksi makuvirheitä.

Tutkimustulosten perusteella kauran keskipakokuorinta rikkoi jyviä erityisesti korkeita kierrosnopeuksia käytettäessä, mutta havaitut jyvävauriot eivät aiheuttaneet rasvojen härskiintymistä eivätkä siten heikentäneet varastoitavuutta. Tämän mukaan viljelijät voivat niin alihankkiessaan kuorinnan kuin investoidessaan itse kauran kuorijaan käsitellä kerralla suuria eriä ilman säilyvyysongelmia. 